\title{
Studi Penentuan Kalor Jenis Air dan Larutan Garam Menggunakan Mikrokontroler Arduino Uno
}

\author{
Valentinus Galih Vidia Putra ${ }^{1 *}$, Andrian Wijayono², Endah Purnomosari ${ }^{3}$, Ngadiono4, \\ Irwan ${ }^{5}$ \\ 1,2,3,4,5 Laboratorium Fisika-Mekatronika, Politeknik STTT Bandung \\ Jalan Jakarta No.31 Bandung, 40272, Indonesia \\ *E-mail: valentinus@kemenperin.go.id
}

\begin{abstract}
Abstrak
Penelitian ini dilakukan untuk menentukan kalor jenis larutan garam dan air murni menggunakan suatu metode pengukuran kalorimeter berbasis mikrokontroler Arduino Uno. Larutan garam dan air dipanaskan menggunakan suatu kawat pemanas dengan nilai $I$ sebesar 2,4 A dan $R$ sebesar 0,54 $\Omega$. Kenaikan suhu air dan larutan garam diukur dengan menggunakan mikrokontroler Arduino Uno dan sensor digital pengukur temperatur tipe DS18B20. Pada penelitian ini, nilai $C v$ air murni dan $C v$ larutan air garam telah ditemukan
\end{abstract}

Kata kunci: Kalor jenis, Mikrokontroler, Arduino Uno.

\section{Abstract}

This research was conducted to determine specific heat of pure water and salt solution using the calorimeter measurement method based on the Arduino Uno microcontroller. The salt solution and pure water solution were heated by the heating wire with $2.4 \mathrm{~A}$ and $0.54 \Omega$. The temperature of the pure water and the salt solution was measured using the Arduino Uno microcontroller and DS18B20 temperature sensor. In this study, the Cv of pure water and salt solution has been found.

Keywords: Specific heat, Microcontroller, Arduino Uno.

\section{PENDAHULUAN}

Penentuan kalor jenis air dalam termodinamika umumnya menggunakan suatu piranti alat konvensional seperti termometer raksa dan juga suatu alat ukur waktu. Dalam bidang fisika dan kimia, kalor jenis air umumnya digunakan untuk menentukan laju panas suatu larutan. Beberapa peneliti, seperti Badamasi, Y. A. (2014), Putra, VGV \& Purnomosari, E, (2015) dan Raine, (1945), González, T.J., Torres, S.R., Blaya, R.P., Toledo, M.A., Jiménez, B.M., \& Soto, V.F. (2019)., Putra, VGV., Ngadiono, \& Purnomosari, E. (2016), Hoffmann, T., Eilebrecht, B., \& Leonhardt, S. (2011), Dean, R. N., \& Rane, A. K. (2013). dan Kondalkar, V. V., Ryu, G., Lee, Y., \& Lee, K. (2019) menggunakan piranti mikrokontroller unutk pengukuran suatu besaran-besaran fisika.

Halliday, D., Resnick, R., Walker. (1997), Putra, V G V, (2017), Putra, VGV., Ngadiono, \&
Purnomosari, E. (2019) dan Sreejith K R ,Shyamkumar P.G, Revathy P. Appu, (2015), menyatakan bahwa arus listrik dalam piranti akan mengahsilkan suatu panas yang diakibatkan pergerakan muatan tiap waktu tertentu. Panas yang dihasilkan dari porgerakan muatan tersebut jika dikenakan pada suatu medium cair akan mengakibatkan pergerakan muatan apda larutan menjadi lebih besar. Laju pergerakan muatan dan gesekan antar muatan akan mengakibatkan panas pada larutan. Beberapa peneliti seperti Putra, VGV. Ngadiono, dan Purnomosari, E. (2019) dan Sreejith K R ,Shyamkumar P.G, Revathy P. Appu, (2015) dan Salvo, P., Di Francesco, F., Costanzo, D., Ferrari, C., Trivella, M. G., \& De Rossi, D. (2010) menyatakan bahwa penelitian tentang panas yang ditimbulkan oleh arus listrik beserta sifat termodinamikanya adalah suatu topik penelitian yang menarik untuk dikaji terutama dnegan suatu piranti alat mikrokontroller 
beserta sensor.

Menurut Halliday, D., Resnick, R., Walker. (1997) dan Putra, V G V, (2017) arus listrik adalah gerakan atau aliran muatan listrik yang pergerakan muatan ini terjadi pada bahan yang disebut konduktor. Konduktor bisa berupa logam, gas (plasma), atau larutan (larutan elektrolit).

Sreejith K R ,Shyamkumar P.G, Revathy P. Appu, (2015), menyatakan bahwa Untuk mengukur suatu benda secara tepat haruslah mempergunakan suatu alat yang mempunyai sifat fisis yang dapat diukur, karena terjadi suatu perubahan yang dapat diukur dengan berubahnya temparatur benda tersebut. Satu kalori didefenisikan sebagai banyaknya kalor yang diperlukan untuk memanaskan satu gram air sehingga suhunya naik satu derajat celcius. Satu kalori setara dengan 4,2 Joule (Putra, VGV \& Purnomosari, E., 2015).

Karena kalor adalah bentuk energi, maka satuan SI untuk kalor sama seperti energi, yaitu Joule. Kalor berpindah dari suhu tinggi ke suhu rendah.

Panas yang ditimbulkan oleh arus listrik memiliki rumus pada persamaan (1) sebagai berikut :

$$
Q=0,24 I^{2} R t
$$

Dengan nilai $Q$ adalah jumlah panas yang timbul (kalori), $I$ adalah kuat arus (ampere), $R$ adalah tahanan (ohm) dan $t$ merupakan waktu (detik).

Menurut Halliday, D., Resnick, R., Walker. (1997) dan Putra, V G V, (2017) suatu zat yang menerima kalor, selain mengalami pemuaian atau perubahan wujud, pada zat tersebut juga terjadi kenaikan suhu. Ketika kita memanaskan air didalam ketel, makin besar nyala api berarti makin besar kalor yang diberikan pada air, dan menghasilkan kenaikan suhu air yang lebih besar daripada kenaikan suhu air sebelumnya. Jika kalor yang sama diberikan pada ketel yang berisi lebih sedikit air, kenaikan suhu air lebih cepat daripada kenaikan suhu air sebelumnya. Akibatnya, untuk selang waktu pemanasan yang sama akan dicapai suhu air yang lebih tinggi daripada sebelumnya. Besarnya kenaikan suhu dari zat tersebut dapat dituliskan dalam persamaan (2) berikut:

$$
Q=m c \Delta T
$$

Dengan nilai $Q$ adalah jumlah panas yang timbul (kalori), $m$ merupakan massa benda (gram), $c$ adalah kalor jenis $(\mathrm{kal} / \mathrm{g})$ dan $\Delta t$ merupakan perubahan suhu.

Menurut Picker, P., Leduc, P.-A., Philip, P. R., \& Desnoyers, J. E. (1971), Halliday, D., Resnick, R., Walker. (1997) dan Putra, V G V, (2017) kalor jenis suatu zat didefinisikan sebagai banyaknya kalor (Joule) yang diperlukan oleh suatu zat untuk menaikan suhu 1 gram zat itu sebesar $1^{\circ} \mathrm{C}$.

Putra, VGV., Ngadiono, \& Purnomosari, E. (2019) dan Sreejith K R , Shyamkumar P.G, Revathy P. Appu, (2015) menyatakan bahwa kapasitas kalor adalah bilangan yang menunjukkan banyaknya kalor (Joule) yang diperlukan oleh oleh suatu benda untuk menaikan suhu $1 \mathrm{gram}$ zat itu sebesar $1^{\circ} \mathrm{C}$. Apabila kapasitas kalor $(C)$ yang dihubungkan dengan kalor jenis $(c)$ maka akan didapat persamaan (3) berikut:

$$
c=m c
$$

Kalorimeter adalah suatu alat untuk memperlihatkan besarnya kalor jenis suatu zat. Kalorimeter ini bekerja berdasarkan Asas Black. Asas Black berbunyi : "Besarnya kalor yang dilepaskan oleh sebuah benda yang suhunya lebih tinggi akan sama dengan kalor yang diterima oleh benda yang bersuhu lebih rendah"

Pada beberapa penelitian lainnya, nilai kalor jenis juga digunakan pula untuk mengetahui efek suhu pada proses pengarangan tempurung kelapa (Tirono, M., \& Sabit, A. 2011). Ackermann, T. (1957) juga menggunakan nilai kalor jenis untuk mengetahui jumlah ion $\mathrm{H}^{+}$dan $\mathrm{OH}^{-}$pada suatu larutan elektrolit.

Terdapat beberapa penelitian terdahulu mengenai pengukuran nilai specific heat suatu larutan. Picker, P., Leduc, P.-A., Philip, P. R., \& Desnoyers, J. E. (1971) telah membuat suatu perangkat untuk mengukur kapasitas panas dari suatu larutan dengan menggunakan sistem mikrokalorimetri. Kemudian Grolier, dkk (1975) juga telah mengembangkan suatu perangkat yang dapat mengukur nilai kalor jenis untuk suatu larutan organik.

Tujuan penelitian ini adalah menghitung 
besar kalor jenis air dan larutan garam dengan menggunakan perangkat mikrokontroler Arduino Uno, serta membandingkan kalor jenis kalor jenis air dan larutan garam. Pengukuran suhu dilakukan dengan menggunakan sensor digital pengukur temperatur tipe DS18B20.

\section{METODE/EKSPERIMEN}

Pada metode eksperimen dijelaskan mengenai alat dan bahan, skema percobaan serta prosedur kerja. Berikut ini merupakan Alat dan Bahan yang digunakan:

1. Kalorimeter

2. Kawat tahanan (kawat pemanas)

3. Sensor pengukur suhu tipe DS18B20

4. Amperemeter

5. Tahanan geser

6. Gelas ukur

7. Batu timbangan

8. Neraca teknis

9. Penghubung arus

10. Slide regulator

11. Kabel penghubung

12. Sumber arus ampere

13. Komputer

14. Aquades/air

15. Garam $/ \mathrm{NaCl}$

Prosedur metode pengukuran kalor jenis dapat dijelaskan sebagai berikut:

1. Menentukan nilai air kalorimeter $(\mathrm{H})$.

2. Menimbang kalorimeter kosong dengan neraca teknis.

3. Mengisi kalorimeter dengan air, kira-kira setengahnya.

4. Menimbang kalorimeter yang telah diisi air.

5. Menyusun rangkaian kalorimeter dengan kabel penghubung ke sumber arus ampere dan menghubungkan rangkaian sensor suhu.

6. Menghubungkan rangkaian ke sumber arus.

7. Mengamati layar komputer yang berisi data perubahan suhu selama 30 menit dengan selang waktu setiap 6,2 sekon.

8. Menghentikan proses setelah 30 menit.

9. Melakukan poses pengambilan data. Data yang diambil dimulai saat suhu sistem sudah mulai stabil.
10. Melakukan langkah 1 s.d. 9 untuk menguji larutan $\mathrm{NaCl}$.

\section{HASIL DAN PEMBAHASAN}

Pengujian kali ini yaitu pengukuran perubahan temperatur pada air murni dengan temperatur awal $\left(T_{o}\right)$ sebesar $28.12^{\circ} \mathrm{C}$ bermassa $(209 \pm 0,005)$ gram yang dipanaskan dengan menggunakan $I$ sebesar $(2,4 \pm 0,01) \mathrm{A}$ dan $R$ sebesar $0,54 \Omega$. Tabel 1 menunjukan data perubahan temperatur dengan pembacaan tiap 6,2 sekon menggunakan perangkat mikrokontroler Arduino Uno serta sensor pengukur suhu tipe DS18B20.

Tabel 1. Data Eksperimen perubahan temperature air murni dengan $I=2,4 \pm 0,01 \mathrm{~A}$ dan $R=0,54 \Omega$

\begin{tabular}{|c|c|c|c|}
\hline $\mathbf{T}$ & $\mathbf{T}_{\mathbf{0}}$ & $\Delta \mathbf{T}$ & $\mathbf{t}$ \\
\hline 28.12 & 28.12 & 0 & 0 \\
\hline 28.12 & 28.12 & 0 & 6.2 \\
\hline 28.37 & 28.12 & 0.25 & 12.4 \\
\hline 28.5 & 28.12 & 0.38 & 18.6 \\
\hline 28.56 & 28.12 & 0.44 & 24.8 \\
\hline 28.62 & 28.12 & 0.5 & 31 \\
\hline 28.69 & 28.12 & 0.57 & 37.2 \\
\hline 28.81 & 28.12 & 0.69 & 43.4 \\
\hline 28.87 & 28.12 & 0.75 & 49.6 \\
\hline 28.87 & 28.12 & 0.75 & 55.8 \\
\hline 28.94 & 28.12 & 0.82 & 62 \\
\hline 29.06 & 28.12 & 0.94 & 68.2 \\
\hline 29.12 & 28.12 & 1 & 74.4 \\
\hline 29.19 & 28.12 & 1.07 & 80.6 \\
\hline 29.19 & 28.12 & 1.07 & 86.8 \\
\hline 29.25 & 28.12 & 1.13 & 93 \\
\hline 29.31 & 28.12 & 1.19 & 99.2 \\
\hline 29.31 & 28.12 & 1.19 & 105.4 \\
\hline 29.31 & 28.12 & 1.19 & 111.6 \\
\hline 29.12 & 28.12 & 1 & 117.8 \\
\hline 29.19 & 28.12 & 1.07 & 124 \\
\hline 29.25 & 28.12 & 1.13 & 130.2 \\
\hline 29.31 & 28.12 & 1.19 & 136.4 \\
\hline 29.37 & 28.12 & 1.25 & 142.6 \\
\hline 29.37 & 28.12 & 1.25 & 148.8 \\
\hline 29.44 & 28.12 & 1.32 & 155 \\
\hline 29.5 & 28.12 & 1.38 & 161.2 \\
\hline
\end{tabular}




\begin{tabular}{|c|c|c|c|}
\hline 29.5 & 28.12 & 1.38 & 167.4 \\
\hline 29.56 & 28.12 & 1.44 & 173.6 \\
\hline 29.56 & 28.12 & 1.44 & 179.8 \\
\hline 29.62 & 28.12 & 1.5 & 186 \\
\hline 29.69 & 28.12 & 1.57 & 192.2 \\
\hline 29.69 & 28.12 & 1.57 & 198.4 \\
\hline 29.75 & 28.12 & 1.63 & 204.6 \\
\hline 29.75 & 28.12 & 1.63 & 210.8 \\
\hline 29.75 & 28.12 & 1.63 & 217 \\
\hline 29.75 & 28.12 & 1.63 & 223.2 \\
\hline 29.75 & 28.12 & 1.63 & 229.4 \\
\hline 29.75 & 28.12 & 1.63 & 235.6 \\
\hline 29.75 & 28.12 & 1.63 & 241.8 \\
\hline 29.81 & 28.12 & 1.69 & 248 \\
\hline 29.81 & 28.12 & 1.69 & 254.2 \\
\hline 29.87 & 28.12 & 1.75 & 260.4 \\
\hline 29.94 & 28.12 & 1.82 & 266.6 \\
\hline 30 & 28.12 & 1.88 & 272.8 \\
\hline 30 & 28.12 & 1.88 & 279 \\
\hline 30 & 28.12 & 1.88 & 285.2 \\
\hline 30.06 & 28.12 & 1.94 & 291.4 \\
\hline 30.06 & 28.12 & 1.94 & 297.6 \\
\hline 29.94 & 28.12 & 1.82 & 303.8 \\
\hline 29.87 & 28.12 & 1.75 & 310 \\
\hline 29.87 & 28.12 & 1.75 & 316.2 \\
\hline 29.81 & 28.12 & 1.69 & 322.4 \\
\hline 29.81 & 28.12 & 1.69 & 328.6 \\
\hline 29.87 & 28.12 & 1.75 & 334.8 \\
\hline 29.87 & 28.12 & 1.75 & 341 \\
\hline 29.87 & 28.12 & 1.75 & 347.2 \\
\hline 29.94 & 28.12 & 1.82 & 353.4 \\
\hline 30 & 28.12 & 1.88 & 359.6 \\
\hline 30.06 & 28.12 & 1.94 & 365.8 \\
\hline 30.12 & 28.12 & 2 & 372 \\
\hline 30.12 & 28.12 & 2 & 378.2 \\
\hline 30.19 & 28.12 & 2.07 & 384.4 \\
\hline 30.19 & 28.12 & 2.07 & 390.6 \\
\hline 30.25 & 28.12 & 2.13 & 396.8 \\
\hline 30.25 & 28.12 & 2.13 & 403 \\
\hline 30.25 & 28.12 & 2.13 & 409.2 \\
\hline 30.25 & 28.12 & 2.13 & 415.4 \\
\hline 30.25 & 28.12 & 2.13 & 421.6 \\
\hline 30.25 & 28.12 & 2.13 & 427.8 \\
\hline
\end{tabular}

\begin{tabular}{|c|c|c|c|}
\hline 30.19 & 28.12 & 2.07 & 434 \\
\hline 30.19 & 28.12 & 2.07 & 440.2 \\
\hline 30.19 & 28.12 & 2.07 & 446.4 \\
\hline 30.12 & 28.12 & 2 & 452.6 \\
\hline 30.12 & 28.12 & 2 & 458.8 \\
\hline 30.19 & 28.12 & 2.07 & 465 \\
\hline 30.25 & 28.12 & 2.13 & 471.2 \\
\hline 30.25 & 28.12 & 2.13 & 477.4 \\
\hline 30.37 & 28.12 & 2.25 & 483.6 \\
\hline 30.37 & 28.12 & 2.25 & 489.8 \\
\hline 30.37 & 28.12 & 2.25 & 496 \\
\hline 30.44 & 28.12 & 2.32 & 502.2 \\
\hline 30.5 & 28.12 & 2.38 & 508.4 \\
\hline 30.5 & 28.12 & 2.38 & 514.6 \\
\hline 30.5 & 28.12 & 2.38 & 520.8 \\
\hline 30.56 & 28.12 & 2.44 & 527 \\
\hline 30.62 & 28.12 & 2.5 & 533.2 \\
\hline 30.62 & 28.12 & 2.5 & 539.4 \\
\hline 30.62 & 28.12 & 2.5 & 545.6 \\
\hline 30.69 & 28.12 & 2.57 & 551.8 \\
\hline 30.69 & 28.12 & 2.57 & 558 \\
\hline 30.69 & 28.12 & 2.57 & 564.2 \\
\hline 30.69 & 28.12 & 2.57 & 570.4 \\
\hline 30.75 & 28.12 & 2.63 & 576.6 \\
\hline 30.75 & 28.12 & 2.63 & 582.8 \\
\hline 30.81 & 28.12 & 2.69 & 589 \\
\hline 30.81 & 28.12 & 2.69 & 595.2 \\
\hline 30.81 & 28.12 & 2.69 & 601.4 \\
\hline 30.87 & 28.12 & 2.75 & 607.6 \\
\hline 30.94 & 28.12 & 2.82 & 613.8 \\
\hline 30.94 & 28.12 & 2.82 & 620 \\
\hline 31 & 28.12 & 2.88 & 626.2 \\
\hline 30.94 & 28.12 & 2.82 & 632.4 \\
\hline 30.94 & 28.12 & 2.82 & 638.6 \\
\hline 30.94 & 28.12 & 2.82 & 644.8 \\
\hline 30.94 & 28.12 & 2.82 & 651 \\
\hline 30.94 & 28.12 & 2.82 & 657.2 \\
\hline 30.94 & 28.12 & 2.82 & 663.4 \\
\hline 30.87 & 28.12 & 2.75 & 669.6 \\
\hline 30.87 & 28.12 & 2.75 & 675.8 \\
\hline 30.87 & 28.12 & 2.75 & 682 \\
\hline 30.94 & 28.12 & 2.82 & 688.2 \\
\hline 30.94 & 28.12 & 2.82 & 694.4 \\
\hline
\end{tabular}


90 | JIPFRI (Jurnal Inovasi Pendidikan Fisika dan Riset IImiah), Vol. 3 No. 2, November 2019

\begin{tabular}{|c|c|c|c|}
\hline 31 & 28.12 & 2.88 & 700.6 \\
\hline 31 & 28.12 & 2.88 & 706.8 \\
\hline 31.06 & 28.12 & 2.94 & 713 \\
\hline 31.06 & 28.12 & 2.94 & 719.2 \\
\hline 31.06 & 28.12 & 2.94 & 725.4 \\
\hline 31.06 & 28.12 & 2.94 & 731.6 \\
\hline 31.12 & 28.12 & 3 & 737.8 \\
\hline 31.19 & 28.12 & 3.07 & 744 \\
\hline 31.19 & 28.12 & 3.07 & 750.2 \\
\hline 31.25 & 28.12 & 3.13 & 756.4 \\
\hline 31.25 & 28.12 & 3.13 & 762.6 \\
\hline 31.25 & 28.12 & 3.13 & 768.8 \\
\hline 31.25 & 28.12 & 3.13 & 775 \\
\hline 31.31 & 28.12 & 3.19 & 781.2 \\
\hline 31.31 & 28.12 & 3.19 & 787.4 \\
\hline 31.31 & 28.12 & 3.19 & 793.6 \\
\hline 31.31 & 28.12 & 3.19 & 799.8 \\
\hline 31.31 & 28.12 & 3.19 & 806 \\
\hline 31.31 & 28.12 & 3.19 & 812.2 \\
\hline 31.31 & 28.12 & 3.19 & 818.4 \\
\hline 31.37 & 28.12 & 3.25 & 824.6 \\
\hline 31.37 & 28.12 & 3.25 & 830.8 \\
\hline 31.44 & 28.12 & 3.32 & 837 \\
\hline 31.44 & 28.12 & 3.32 & 843.2 \\
\hline 31.5 & 28.12 & 3.38 & 849.4 \\
\hline 31.5 & 28.12 & 3.38 & 855.6 \\
\hline 31.5 & 28.12 & 3.38 & 861.8 \\
\hline 31.5 & 28.12 & 3.38 & 868 \\
\hline 31.5 & 28.12 & 3.38 & 874.2 \\
\hline 31.5 & 28.12 & 3.38 & 880.4 \\
\hline 31.56 & 28.12 & 3.44 & 886.6 \\
\hline 31.56 & 28.12 & 3.44 & 892.8 \\
\hline 31.56 & 28.12 & 3.44 & 899 \\
\hline 31.56 & 28.12 & 3.44 & 905.2 \\
\hline 31.56 & 28.12 & 3.44 & 911.4 \\
\hline 31.62 & 28.12 & 3.5 & 917.6 \\
\hline 31.69 & 28.12 & 3.57 & 923.8 \\
\hline 31.69 & 28.12 & 3.57 & 930 \\
\hline 31.69 & 28.12 & 3.57 & 936.2 \\
\hline 31.37 & 28.12 & 3.25 & 942.4 \\
\hline 31.31 & 28.12 & 3.19 & 948.6 \\
\hline 31.37 & 28.12 & 3.25 & 954.8 \\
\hline 31.44 & 28.12 & 3.32 & 961 \\
\hline 31.5 & 28.12 & 3.38 & 967.2 \\
\hline
\end{tabular}

\begin{tabular}{|c|c|c|c|}
\hline 31.56 & 28.12 & 3.44 & 973.4 \\
\hline 31.62 & 28.12 & 3.5 & 979.6 \\
\hline 31.69 & 28.12 & 3.57 & 985.8 \\
\hline 31.75 & 28.12 & 3.63 & 992 \\
\hline 31.81 & 28.12 & 3.69 & 998.2 \\
\hline 31.81 & 28.12 & 3.69 & 1004.4 \\
\hline 31.81 & 28.12 & 3.69 & 1010.6 \\
\hline 31.87 & 28.12 & 3.75 & 1016.8 \\
\hline 31.87 & 28.12 & 3.75 & 1023 \\
\hline 31.94 & 28.12 & 3.82 & 1029.2 \\
\hline 31.94 & 28.12 & 3.82 & 1035.4 \\
\hline 32 & 28.12 & 3.88 & 1041.6 \\
\hline 32 & 28.12 & 3.88 & 1047.8 \\
\hline 32 & 28.12 & 3.88 & 1054 \\
\hline 32.06 & 28.12 & 3.94 & 1060.2 \\
\hline 32.06 & 28.12 & 3.94 & 1066.4 \\
\hline 32.06 & 28.12 & 3.94 & 1072.6 \\
\hline 32.13 & 28.12 & 4.01 & 1078.8 \\
\hline 32.06 & 28.12 & 3.94 & 1085 \\
\hline 32.13 & 28.12 & 4.01 & 1091.2 \\
\hline 32.13 & 28.12 & 4.01 & 1097.4 \\
\hline 32.13 & 28.12 & 4.01 & 1103.6 \\
\hline 32.13 & 28.12 & 4.01 & 1109.8 \\
\hline 32.06 & 28.12 & 3.94 & 1116 \\
\hline 32.13 & 28.12 & 4.01 & 1122.2 \\
\hline 32.06 & 28.12 & 3.94 & 1128.4 \\
\hline 32.13 & 28.12 & 4.01 & 1134.6 \\
\hline 32.19 & 28.12 & 4.07 & 1140.8 \\
\hline 32.25 & 28.12 & 4.13 & 1147 \\
\hline 32.25 & 28.12 & 4.13 & 1153.2 \\
\hline 32.25 & 28.12 & 4.13 & 1159.4 \\
\hline 32.19 & 28.12 & 4.07 & 1165.6 \\
\hline 32.19 & 28.12 & 4.07 & 1171.8 \\
\hline 32.25 & 28.12 & 4.13 & 1178 \\
\hline 32.31 & 28.12 & 4.19 & 1184.2 \\
\hline 32.31 & 28.12 & 4.19 & 1190.4 \\
\hline 32.38 & 28.12 & 4.26 & 1196.6 \\
\hline 32.38 & 28.12 & 4.26 & 1202.8 \\
\hline 32.44 & 28.12 & 4.32 & 1209 \\
\hline 32.5 & 28.12 & 4.38 & 1215.2 \\
\hline 32.5 & 28.12 & 4.38 & 1221.4 \\
\hline 32.56 & 28.12 & 4.44 & 1227.6 \\
\hline 32.5 & 28.12 & 4.38 & 1233.8 \\
\hline 32.5 & 28.12 & 4.38 & 1240 \\
\hline
\end{tabular}




\begin{tabular}{|c|c|c|c|}
\hline 32.5 & 28.12 & 4.38 & 1246.2 \\
\hline 32.56 & 28.12 & 4.44 & 1252.4 \\
\hline 32.56 & 28.12 & 4.44 & 1258.6 \\
\hline 32.56 & 28.12 & 4.44 & 1264.8 \\
\hline 32.56 & 28.12 & 4.44 & 1271 \\
\hline 32.63 & 28.12 & 4.51 & 1277.2 \\
\hline 32.63 & 28.12 & 4.51 & 1283.4 \\
\hline 32.69 & 28.12 & 4.57 & 1289.6 \\
\hline 32.69 & 28.12 & 4.57 & 1295.8 \\
\hline 32.69 & 28.12 & 4.57 & 1302 \\
\hline 32.69 & 28.12 & 4.57 & 1308.2 \\
\hline 32.69 & 28.12 & 4.57 & 1314.4 \\
\hline 32.63 & 28.12 & 4.51 & 1320.6 \\
\hline 32.75 & 28.12 & 4.63 & 1326.8 \\
\hline 32.81 & 28.12 & 4.69 & 1333 \\
\hline 32.81 & 28.12 & 4.69 & 1339.2 \\
\hline 32.81 & 28.12 & 4.69 & 1345.4 \\
\hline 32.94 & 28.12 & 4.82 & 1351.6 \\
\hline 32.94 & 28.12 & 4.82 & 1357.8 \\
\hline 32.94 & 28.12 & 4.82 & 1364 \\
\hline 32.94 & 28.12 & 4.82 & 1370.2 \\
\hline 32.88 & 28.12 & 4.76 & 1376.4 \\
\hline 32.94 & 28.12 & 4.82 & 1382.6 \\
\hline 32.94 & 28.12 & 4.82 & 1388.8 \\
\hline 32.94 & 28.12 & 4.82 & 1395 \\
\hline 32.94 & 28.12 & 4.82 & 1401.2 \\
\hline 32.94 & 28.12 & 4.82 & 1407.4 \\
\hline 32.88 & 28.12 & 4.76 & 1413.6 \\
\hline 32.88 & 28.12 & 4.76 & 1419.8 \\
\hline 32.94 & 28.12 & 4.82 & 1426 \\
\hline 32.94 & 28.12 & 4.82 & 1432.2 \\
\hline 32.94 & 28.12 & 4.82 & 1438.4 \\
\hline 32.94 & 28.12 & 4.82 & 1444.6 \\
\hline 33 & 28.12 & 4.88 & 1450.8 \\
\hline 33 & 28.12 & 4.88 & 1457 \\
\hline 33.06 & 28.12 & 4.94 & 1463.2 \\
\hline 33.06 & 28.12 & 4.94 & 1469.4 \\
\hline 33.06 & 28.12 & 4.94 & 1475.6 \\
\hline 33.06 & 28.12 & 4.94 & 1481.8 \\
\hline 33.06 & 28.12 & 4.94 & 1488 \\
\hline 33.06 & 28.12 & 4.94 & 1494.2 \\
\hline 33.13 & 28.12 & 5.01 & 1500.4 \\
\hline 33.06 & 28.12 & 4.94 & 1506.6 \\
\hline
\end{tabular}

\begin{tabular}{|c|c|c|c|}
\hline 33.06 & 28.12 & 4.94 & 1512.8 \\
\hline 33.06 & 28.12 & 4.94 & 1519 \\
\hline 33.13 & 28.12 & 5.01 & 1525.2 \\
\hline 33.19 & 28.12 & 5.07 & 1531.4 \\
\hline 33.25 & 28.12 & 5.13 & 1537.6 \\
\hline 33.19 & 28.12 & 5.07 & 1543.8 \\
\hline 33.19 & 28.12 & 5.07 & 1550 \\
\hline 33.25 & 28.12 & 5.13 & 1556.2 \\
\hline 33.31 & 28.12 & 5.19 & 1562.4 \\
\hline 33.31 & 28.12 & 5.19 & 1568.6 \\
\hline 33.31 & 28.12 & 5.19 & 1574.8 \\
\hline 33.31 & 28.12 & 5.19 & 1581 \\
\hline 33.25 & 28.12 & 5.13 & 1587.2 \\
\hline 33.25 & 28.12 & 5.13 & 1593.4 \\
\hline 33.31 & 28.12 & 5.19 & 1599.6 \\
\hline 33.31 & 28.12 & 5.19 & 1605.8 \\
\hline 33.38 & 28.12 & 5.26 & 1612 \\
\hline 33.38 & 28.12 & 5.26 & 1618.2 \\
\hline 33.38 & 28.12 & 5.26 & 1624.4 \\
\hline 33.38 & 28.12 & 5.26 & 1630.6 \\
\hline 33.38 & 28.12 & 5.26 & 1636.8 \\
\hline
\end{tabular}

Pengujian kedua yaitu pengukuran perubahan temperatur pada air murni dengan temperatur awal $\left(T_{o}\right)$ sebesar $28.81^{\circ} \mathrm{C}$ bermassa $(209 \pm 0,005)$ gram yang dipanaskan dengan menggunakan $I$ sebesar $(2,4 \pm 0,01) \mathrm{A}$ dan $R$ sebesar $0,54 \Omega$. Tabel 2 menunjukan data perubahan temperatur dengan pembacaan tiap 6,2 sekon menggunakan perangkat mikrokontroler Arduino Uno serta sensor pengukur suhu tipe DS18B20.

Tabel 2. Data Eksperimen perubahan temperature air garam dengan $I=2,4 \pm 0,01 \mathrm{~A}$ dan $R=0,54 \Omega$

\begin{tabular}{|c|c|c|c|}
\hline $\mathbf{T}$ & $\mathbf{T 0}$ & $\Delta \mathbf{T}$ & $\mathbf{T}$ \\
\hline 28.81 & 28.81 & 0 & 0 \\
\hline 28.87 & 28.81 & 0.06 & 6.2 \\
\hline 28.94 & 28.81 & 0.13 & 12.4 \\
\hline 29 & 28.81 & 0.19 & 18.6 \\
\hline 29.06 & 28.81 & 0.25 & 24.8 \\
\hline 29.06 & 28.81 & 0.25 & 31 \\
\hline 29.12 & 28.81 & 0.31 & 37.2 \\
\hline 29.19 & 28.81 & 0.38 & 43.4 \\
\hline
\end{tabular}


92 | JIPFRI (Jurnal Inovasi Pendidikan Fisika dan Riset Ilmiah), Vol. 3 No. 2, November 2019

\begin{tabular}{|c|c|c|c|}
\hline 29.25 & 28.81 & 0.44 & 49.6 \\
\hline 29.25 & 28.81 & 0.44 & 55.8 \\
\hline 29.31 & 28.81 & 0.5 & 62 \\
\hline 29.31 & 28.81 & 0.5 & 68.2 \\
\hline 29.37 & 28.81 & 0.56 & 74.4 \\
\hline 29.37 & 28.81 & 0.56 & 80.6 \\
\hline 29.44 & 28.81 & 0.63 & 86.8 \\
\hline 29.44 & 28.81 & 0.63 & 93 \\
\hline 29.44 & 28.81 & 0.63 & 99.2 \\
\hline 29.44 & 28.81 & 0.63 & 105.4 \\
\hline 29.44 & 28.81 & 0.63 & 111.6 \\
\hline 29.5 & 28.81 & 0.69 & 117.8 \\
\hline 29.44 & 28.81 & 0.63 & 124 \\
\hline 29.44 & 28.81 & 0.63 & 130.2 \\
\hline 29.44 & 28.81 & 0.63 & 136.4 \\
\hline 29.44 & 28.81 & 0.63 & 142.6 \\
\hline 29.5 & 28.81 & 0.69 & 148.8 \\
\hline 29.5 & 28.81 & 0.69 & 155 \\
\hline 29.56 & 28.81 & 0.75 & 161.2 \\
\hline 29.56 & 28.81 & 0.75 & 167.4 \\
\hline 29.56 & 28.81 & 0.75 & 173.6 \\
\hline 29.62 & 28.81 & 0.81 & 179.8 \\
\hline 29.62 & 28.81 & 0.81 & 186 \\
\hline 29.69 & 28.81 & 0.88 & 192.2 \\
\hline 29.69 & 28.81 & 0.88 & 198.4 \\
\hline 29.69 & 28.81 & 0.88 & 204.6 \\
\hline 29.75 & 28.81 & 0.94 & 210.8 \\
\hline 29.75 & 28.81 & 0.94 & 217 \\
\hline 29.75 & 28.81 & 0.94 & 223.2 \\
\hline 29.81 & 28.81 & 1 & 229.4 \\
\hline 29.81 & 28.81 & 1 & 235.6 \\
\hline 29.81 & 28.81 & 1 & 241.8 \\
\hline 29.81 & 28.81 & 1 & 248 \\
\hline 29.81 & 28.81 & 1 & 254.2 \\
\hline 29.75 & 28.81 & 0.94 & 260.4 \\
\hline 29.75 & 28.81 & 0.94 & 266.6 \\
\hline 29.75 & 28.81 & 0.94 & 272.8 \\
\hline 29.81 & 28.81 & 1 & 279 \\
\hline 29.75 & 28.81 & 0.94 & 285.2 \\
\hline 29.75 & 28.81 & 0.94 & 291.4 \\
\hline 29.75 & 28.81 & 0.94 & 297.6 \\
\hline 29.81 & 28.81 & 1 & 303.8 \\
\hline 29.81 & 28.81 & 1 & 310 \\
\hline 29.81 & 28.81 & 1 & 316.2 \\
\hline
\end{tabular}

\begin{tabular}{|c|c|c|c|}
\hline 29.81 & 28.81 & 1 & 322.4 \\
\hline 29.87 & 28.81 & 1.06 & 328.6 \\
\hline 29.94 & 28.81 & 1.13 & 334.8 \\
\hline 29.94 & 28.81 & 1.13 & 341 \\
\hline 29.94 & 28.81 & 1.13 & 347.2 \\
\hline 29.94 & 28.81 & 1.13 & 353.4 \\
\hline 29.94 & 28.81 & 1.13 & 359.6 \\
\hline 29.94 & 28.81 & 1.13 & 365.8 \\
\hline 29.94 & 28.81 & 1.13 & 372 \\
\hline 29.94 & 28.81 & 1.13 & 378.2 \\
\hline 30 & 28.81 & 1.19 & 384.4 \\
\hline 30 & 28.81 & 1.19 & 390.6 \\
\hline 30 & 28.81 & 1.19 & 396.8 \\
\hline 30 & 28.81 & 1.19 & 403 \\
\hline 30.06 & 28.81 & 1.25 & 409.2 \\
\hline 30.06 & 28.81 & 1.25 & 415.4 \\
\hline 30.12 & 28.81 & 1.31 & 421.6 \\
\hline 30.12 & 28.81 & 1.31 & 427.8 \\
\hline 30.19 & 28.81 & 1.38 & 434 \\
\hline 30.19 & 28.81 & 1.38 & 440.2 \\
\hline 30.19 & 28.81 & 1.38 & 446.4 \\
\hline 30.25 & 28.81 & 1.44 & 452.6 \\
\hline 30.31 & 28.81 & 1.5 & 458.8 \\
\hline 30.31 & 28.81 & 1.5 & 465 \\
\hline 30.31 & 28.81 & 1.5 & 471.2 \\
\hline 30.37 & 28.81 & 1.56 & 477.4 \\
\hline 30.37 & 28.81 & 1.56 & 483.6 \\
\hline 30.44 & 28.81 & 1.63 & 489.8 \\
\hline 30.44 & 28.81 & 1.63 & 496 \\
\hline 30.44 & 28.81 & 1.63 & 502.2 \\
\hline 30.44 & 28.81 & 1.63 & 508.4 \\
\hline 30.44 & 28.81 & 1.63 & 514.6 \\
\hline 30.44 & 28.81 & 1.63 & 520.8 \\
\hline 30.44 & 28.81 & 1.63 & 527 \\
\hline 30.44 & 28.81 & 1.63 & 533.2 \\
\hline 30.44 & 28.81 & 1.63 & 539.4 \\
\hline 30.44 & 28.81 & 1.63 & 545.6 \\
\hline 30.44 & 28.81 & 1.63 & 551.8 \\
\hline 30.44 & 28.81 & 1.63 & 558 \\
\hline 30.44 & 28.81 & 1.63 & 564.2 \\
\hline 30.5 & 28.81 & 1.69 & 570.4 \\
\hline 30.5 & 28.81 & 1.69 & 576.6 \\
\hline 30.56 & 28.81 & 1.75 & 582.8 \\
\hline 30.56 & 28.81 & 1.75 & 589 \\
\hline
\end{tabular}




\begin{tabular}{|c|c|c|c|}
\hline 30.62 & 28.81 & 1.81 & 595.2 \\
\hline 30.69 & 28.81 & 1.88 & 601.4 \\
\hline 30.69 & 28.81 & 1.88 & 607.6 \\
\hline 30.75 & 28.81 & 1.94 & 613.8 \\
\hline 30.81 & 28.81 & 2 & 620 \\
\hline 30.81 & 28.81 & 2 & 626.2 \\
\hline 30.87 & 28.81 & 2.06 & 632.4 \\
\hline 30.87 & 28.81 & 2.06 & 638.6 \\
\hline 30.94 & 28.81 & 2.13 & 644.8 \\
\hline 30.94 & 28.81 & 2.13 & 651 \\
\hline 31 & 28.81 & 2.19 & 657.2 \\
\hline 31.06 & 28.81 & 2.25 & 663.4 \\
\hline 31.06 & 28.81 & 2.25 & 669.6 \\
\hline 31.06 & 28.81 & 2.25 & 675.8 \\
\hline 31.06 & 28.81 & 2.25 & 682 \\
\hline 31.06 & 28.81 & 2.25 & 688.2 \\
\hline 31.12 & 28.81 & 2.31 & 694.4 \\
\hline 31.12 & 28.81 & 2.31 & 700.6 \\
\hline 31.12 & 28.81 & 2.31 & 706.8 \\
\hline 31.19 & 28.81 & 2.38 & 713 \\
\hline 31.19 & 28.81 & 2.38 & 719.2 \\
\hline 31.19 & 28.81 & 2.38 & 725.4 \\
\hline 31.19 & 28.81 & 2.38 & 731.6 \\
\hline 31.19 & 28.81 & 2.38 & 737.8 \\
\hline 31.19 & 28.81 & 2.38 & 744 \\
\hline 31.25 & 28.81 & 2.44 & 750.2 \\
\hline 31.25 & 28.81 & 2.44 & 756.4 \\
\hline 31.31 & 28.81 & 2.5 & 762.6 \\
\hline 31.31 & 28.81 & 2.5 & 768.8 \\
\hline 31.31 & 28.81 & 2.5 & 775 \\
\hline 31.31 & 28.81 & 2.5 & 781.2 \\
\hline 31.37 & 28.81 & 2.56 & 787.4 \\
\hline 31.37 & 28.81 & 2.56 & 793.6 \\
\hline 31.37 & 28.81 & 2.56 & 799.8 \\
\hline 31.44 & 28.81 & 2.63 & 806 \\
\hline 31.44 & 28.81 & 2.63 & 812.2 \\
\hline 31.44 & 28.81 & 2.63 & 818.4 \\
\hline 31.31 & 28.81 & 2.5 & 824.6 \\
\hline 31.37 & 28.81 & 2.56 & 830.8 \\
\hline 31.37 & 28.81 & 2.56 & 837 \\
\hline 31.37 & 28.81 & 2.56 & 843.2 \\
\hline 31.37 & 28.81 & 2.56 & 849.4 \\
\hline 31.44 & 28.81 & 2.63 & 855.6 \\
\hline
\end{tabular}

\begin{tabular}{|c|c|c|c|}
\hline 31.44 & 28.81 & 2.63 & 861.8 \\
\hline 31.5 & 28.81 & 2.69 & 868 \\
\hline 31.5 & 28.81 & 2.69 & 874.2 \\
\hline 31.56 & 28.81 & 2.75 & 880.4 \\
\hline 31.56 & 28.81 & 2.75 & 886.6 \\
\hline 31.56 & 28.81 & 2.75 & 892.8 \\
\hline 31.62 & 28.81 & 2.81 & 899 \\
\hline 31.62 & 28.81 & 2.81 & 905.2 \\
\hline 31.69 & 28.81 & 2.88 & 911.4 \\
\hline 31.69 & 28.81 & 2.88 & 917.6 \\
\hline 31.69 & 28.81 & 2.88 & 923.8 \\
\hline 31.75 & 28.81 & 2.94 & 930 \\
\hline 31.75 & 28.81 & 2.94 & 936.2 \\
\hline 31.75 & 28.81 & 2.94 & 942.4 \\
\hline 31.81 & 28.81 & 3 & 948.6 \\
\hline 31.81 & 28.81 & 3 & 954.8 \\
\hline 31.81 & 28.81 & 3 & 961 \\
\hline 31.81 & 28.81 & 3 & 967.2 \\
\hline 31.87 & 28.81 & 3.06 & 973.4 \\
\hline 31.87 & 28.81 & 3.06 & 979.6 \\
\hline 31.94 & 28.81 & 3.13 & 985.8 \\
\hline 31.94 & 28.81 & 3.13 & 992 \\
\hline 31.94 & 28.81 & 3.13 & 998.2 \\
\hline 32 & 28.81 & 3.19 & 1004.4 \\
\hline 32 & 28.81 & 3.19 & 1010.6 \\
\hline 32 & 28.81 & 3.19 & 1016.8 \\
\hline 32 & 28.81 & 3.19 & 1023 \\
\hline 32.06 & 28.81 & 3.25 & 1029.2 \\
\hline 32.06 & 28.81 & 3.25 & 1035.4 \\
\hline 32.06 & 28.81 & 3.25 & 1041.6 \\
\hline 32.06 & 28.81 & 3.25 & 1047.8 \\
\hline 32.06 & 28.81 & 3.25 & 1054 \\
\hline 32.06 & 28.81 & 3.25 & 1060.2 \\
\hline 32.06 & 28.81 & 3.25 & 1066.4 \\
\hline 32.06 & 28.81 & 3.25 & 1072.6 \\
\hline 32.13 & 28.81 & 3.32 & 1078.8 \\
\hline 32.13 & 28.81 & 3.32 & 1085 \\
\hline 32.19 & 28.81 & 3.38 & 1091.2 \\
\hline 32.19 & 28.81 & 3.38 & 1097.4 \\
\hline 32.19 & 28.81 & 3.38 & 1103.6 \\
\hline 32.19 & 28.81 & 3.38 & 1109.8 \\
\hline 32.19 & 28.81 & 3.38 & 1116 \\
\hline 32.19 & 28.81 & 3.38 & 1122.2 \\
\hline
\end{tabular}


94 | JIPFRI (Jurnal Inovasi Pendidikan Fisika dan Riset Ilmiah), Vol. 3 No. 2, November 2019

\begin{tabular}{|c|c|c|c|}
\hline 32.25 & 28.81 & 3.44 & 1128.4 \\
\hline 32.25 & 28.81 & 3.44 & 1134.6 \\
\hline 32.25 & 28.81 & 3.44 & 1140.8 \\
\hline 32.25 & 28.81 & 3.44 & 1147 \\
\hline 32.25 & 28.81 & 3.44 & 1153.2 \\
\hline 32.31 & 28.81 & 3.5 & 1159.4 \\
\hline 32.31 & 28.81 & 3.5 & 1165.6 \\
\hline 32.31 & 28.81 & 3.5 & 1171.8 \\
\hline 32.31 & 28.81 & 3.5 & 1178 \\
\hline 32.31 & 28.81 & 3.5 & 1184.2 \\
\hline 32.38 & 28.81 & 3.57 & 1190.4 \\
\hline 32.38 & 28.81 & 3.57 & 1196.6 \\
\hline 32.31 & 28.81 & 3.5 & 1202.8 \\
\hline 32.31 & 28.81 & 3.5 & 1209 \\
\hline 32.31 & 28.81 & 3.5 & 1215.2 \\
\hline 32.31 & 28.81 & 3.5 & 1221.4 \\
\hline 32.31 & 28.81 & 3.5 & 1227.6 \\
\hline 32.31 & 28.81 & 3.5 & 1233.8 \\
\hline 32.38 & 28.81 & 3.57 & 1240 \\
\hline 32.25 & 28.81 & 3.44 & 1246.2 \\
\hline 32.25 & 28.81 & 3.44 & 1252.4 \\
\hline 32.25 & 28.81 & 3.44 & 1258.6 \\
\hline 32.25 & 28.81 & 3.44 & 1264.8 \\
\hline 32.25 & 28.81 & 3.44 & 1271 \\
\hline 32.31 & 28.81 & 3.5 & 1277.2 \\
\hline 32.31 & 28.81 & 3.5 & 1283.4 \\
\hline 32.31 & 28.81 & 3.5 & 1289.6 \\
\hline 32.38 & 28.81 & 3.57 & 1295.8 \\
\hline 32.38 & 28.81 & 3.57 & 1302 \\
\hline 32.44 & 28.81 & 3.63 & 1308.2 \\
\hline 32.44 & 28.81 & 3.63 & 1314.4 \\
\hline 32.31 & 28.81 & 3.5 & 1320.6 \\
\hline 32.25 & 28.81 & 3.44 & 1326.8 \\
\hline 32.25 & 28.81 & 3.44 & 1333 \\
\hline 32.31 & 28.81 & 3.5 & 1339.2 \\
\hline 32.38 & 28.81 & 3.57 & 1345.4 \\
\hline 32.38 & 28.81 & 3.57 & 1351.6 \\
\hline 32.44 & 28.81 & 3.63 & 1357.8 \\
\hline 32.5 & 28.81 & 3.69 & 1364 \\
\hline 32.56 & 28.81 & 3.75 & 1370.2 \\
\hline 32.56 & 28.81 & 3.75 & 1376.4 \\
\hline 32.5 & 28.81 & 3.69 & 1382.6 \\
\hline 32.5 & 28.81 & 3.69 & 1388.8 \\
\hline 32.5 & 28.81 & 3.69 & 1395 \\
\hline
\end{tabular}

\begin{tabular}{|c|c|c|c|}
\hline 32.56 & 28.81 & 3.75 & 1401.2 \\
\hline 32.63 & 28.81 & 3.82 & 1407.4 \\
\hline 32.63 & 28.81 & 3.82 & 1413.6 \\
\hline 32.69 & 28.81 & 3.88 & 1419.8 \\
\hline 32.69 & 28.81 & 3.88 & 1426 \\
\hline 32.75 & 28.81 & 3.94 & 1432.2 \\
\hline 32.75 & 28.81 & 3.94 & 1438.4 \\
\hline 32.81 & 28.81 & 4 & 1444.6 \\
\hline 32.81 & 28.81 & 4 & 1450.8 \\
\hline 32.81 & 28.81 & 4 & 1457 \\
\hline 32.81 & 28.81 & 4 & 1463.2 \\
\hline 32.88 & 28.81 & 4.07 & 1469.4 \\
\hline 32.88 & 28.81 & 4.07 & 1475.6 \\
\hline 32.88 & 28.81 & 4.07 & 1481.8 \\
\hline 32.94 & 28.81 & 4.13 & 1488 \\
\hline 32.88 & 28.81 & 4.07 & 1494.2 \\
\hline 32.81 & 28.81 & 4 & 1500.4 \\
\hline 32.63 & 28.81 & 3.82 & 1506.6 \\
\hline 32.63 & 28.81 & 3.82 & 1512.8 \\
\hline 32.63 & 28.81 & 3.82 & 1519 \\
\hline 32.56 & 28.81 & 3.75 & 1525.2 \\
\hline 32.56 & 28.81 & 3.75 & 1531.4 \\
\hline 32.56 & 28.81 & 3.75 & 1537.6 \\
\hline 32.63 & 28.81 & 3.82 & 1543.8 \\
\hline 32.63 & 28.81 & 3.82 & 1550 \\
\hline 32.69 & 28.81 & 3.88 & 1556.2 \\
\hline 32.69 & 28.81 & 3.88 & 1562.4 \\
\hline 32.75 & 28.81 & 3.94 & 1568.6 \\
\hline 32.81 & 28.81 & 4 & 1574.8 \\
\hline 32.81 & 28.81 & 4 & 1581 \\
\hline 32.88 & 28.81 & 4.07 & 1587.2 \\
\hline 32.94 & 28.81 & 4.13 & 1593.4 \\
\hline 32.94 & 28.81 & 4.13 & 1599.6 \\
\hline 32.94 & 28.81 & 4.13 & 1605.8 \\
\hline 33 & 28.81 & 4.19 & 1612 \\
\hline 33.06 & 28.81 & 4.25 & 1618.2 \\
\hline 33.06 & 28.81 & 4.25 & 1624.4 \\
\hline 33.06 & 28.81 & 4.25 & 1630.6 \\
\hline 33.13 & 28.81 & 4.32 & 1636.8 \\
\hline 33.13 & 28.81 & 4.32 & 1643 \\
\hline 33.13 & 28.81 & 4.32 & 1649.2 \\
\hline 33.13 & 28.81 & 4.32 & 1655.4 \\
\hline 33.13 & 28.81 & 4.32 & 1661.6 \\
\hline 33.13 & 28.81 & 4.32 & 1667.8 \\
\hline
\end{tabular}


Berdasarkan data perubahan suhu pada Tabel 1, dapat diketahui hubungan antara waktu (sekon) terhadap perubahan suhu $\left({ }^{\circ} \mathrm{C}\right)$ pada larutan air murni. Gambar 1 memperlihatkan grafik hubungan antara waktu (sekon) terhadap perubahan suhu $\left({ }^{\circ} \mathrm{C}\right)$ pada larutan air murni.

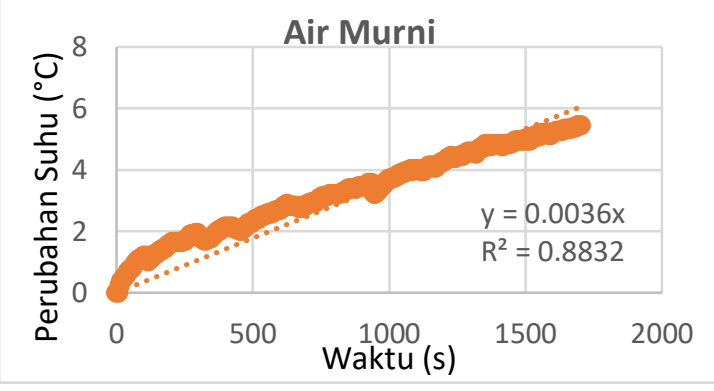

Gambar 1. Hubungan antara waktu (sekon) terhadap perubahan suhu $\left({ }^{\circ} \mathrm{C}\right)$ pada larutan air murni.

Untuk mendapatkan kalor jenis air murni dapat digunakan persamaan (4) hingga persamaan (8) sebagai berikut:

$$
\begin{gathered}
M_{1}=\frac{\Delta T_{\text {akhir }}-\Delta T_{\text {awal }}}{t_{\text {akhir }}-t_{\text {awal }}}=\frac{5,44-0}{1705-0} \\
=0,0031^{\circ} \mathrm{C} / \mathrm{s} \\
M_{2}=\frac{\Delta T_{\text {akhir }}-\Delta T_{\text {awal }}}{t_{\text {akhir }}-t_{\text {awal }}}=\frac{2,13-0}{427,8-0} \\
=0,0049^{\circ} \mathrm{C} / \mathrm{s} \\
\left|\Delta M_{\text {grad }}\right|=\frac{\left|M_{1}-M_{\text {grad }}\right|+\left|M_{2}-M_{\text {grad }}\right|}{2} \\
=\frac{|0,0031-0,0036|+|0,0049-0,0036|}{2} \\
=0,0004^{\circ} \mathrm{C} / \mathrm{s}
\end{gathered}
$$

Besar nilai laju panas, $v$, dapat dituliskan pada persamaan (7)

$$
\begin{aligned}
\mathrm{v} \pm \Delta \mathrm{v}=\mathrm{M}_{\text {gradien }} & \pm \Delta \mathrm{M}_{\text {gradien }} \\
& =(0,0036 \\
& \pm 0,0004)^{\circ} \mathrm{C} / \mathrm{s}
\end{aligned}
$$

Nilai kalor jenis $C v$ dapat dituliskan sebagai persamaan (8) berikut:

$$
\begin{aligned}
C v=\frac{I^{2} R}{m \cdot M \operatorname{Mrad}}= & \frac{(2,4)^{2} \cdot 0,54}{209 \cdot 0,0036} \\
& =\frac{3,1104}{0,7524} \\
& =4,13 \mathrm{~J} / \text { gram }^{\circ} \mathrm{C}
\end{aligned}
$$

Nilai ralat atau angka ketidakpastian besar kalor jenis dapat dituliskan sebagai persamaan (9) berikut:

$$
\begin{aligned}
& |\Delta C v|=\mid \frac{\partial C v}{\partial M g r a d} \cdot \Delta \text { Mgrad } \mid \\
& =\left|\frac{\frac{I^{2} R}{\text { m.Mgrad }}}{\text { Mgrad }} \cdot \Delta M g r a d\right| \\
& =\mid \frac{I^{2} R}{\text { m. Mgrad }^{2}} \cdot \Delta \text { Mgrad } \mid \\
& =\left|\frac{(2,4)^{2} \cdot(0,54)}{209 \cdot(0,0036)^{2}} \cdot 0,0004\right| \\
& =1,72{\mathrm{~J} / \text { ram }^{\circ} \mathrm{C}}^{\circ}
\end{aligned}
$$

Besar kalor jenis air total dapat dituliskan sebagai eprsamaan (10) di bawah

$(C v \pm \Delta C v)$

$$
=(4,13 \pm 1,72) \mathrm{J} \mathrm{gram}^{\circ} \mathrm{C}
$$

Berdasarkan data perubahan suhu pada Tabel 2, dapat diketahui hubungan antara waktu (sekon) terhadap perubahan suhu $\left({ }^{\circ} \mathrm{C}\right)$ pada larutan air garam. Gambar 2 memperlihatkan grafik hubungan antara waktu (sekon) terhadap perubahan suhu $\left({ }^{\circ} \mathrm{C}\right)$ pada larutan air garam.

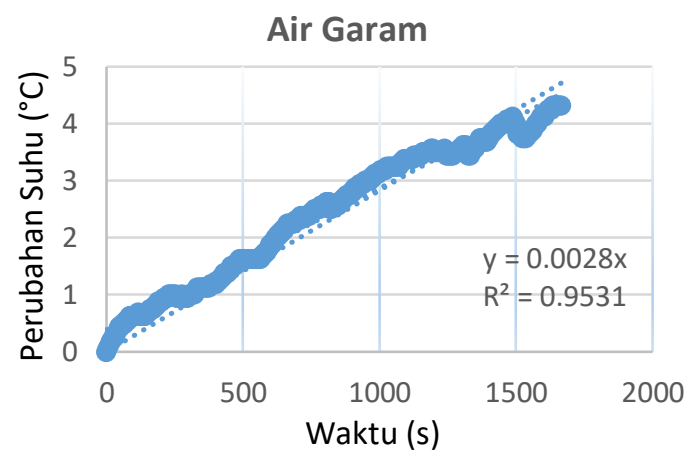

Gambar 2. Hubungan antara waktu (sekon) terhadap perubahan suhu $\left({ }^{\circ} \mathrm{C}\right)$ pada larutan air garam.

Untuk mendapatkan kalor jenis air garam dapat digunakan persamaan (11) hingga persamaan (16) sebagai berikut:

$$
\begin{array}{r}
M_{1}=\frac{\Delta T_{\text {akhir }}-\Delta T_{\text {awal }}}{t_{\text {akhir }}-t_{\text {awal }}}=\frac{4,32-0}{1667,8-0} \\
=0,0025^{\circ} \mathrm{C} / \mathrm{s} \\
M_{2}=\frac{\Delta T_{\text {akhir }}-\Delta T_{\text {awal }}}{t_{\text {akhir }}-t_{\text {awal }}}=\frac{1,81-0}{595,2-0} \\
=0,0030^{\circ} \mathrm{C} / \mathrm{s}
\end{array}
$$




$$
\begin{array}{r}
\left|\Delta M_{\text {grad }}\right|=\frac{\left|M_{1}-M_{\text {grad }}\right|+\left|M_{2}-M_{\text {grad }}\right|}{2} \\
=\frac{|0,0025-0,0028|+|0,0030-0,0028|}{2} \\
=\frac{0,0003+0,0002}{2} \\
=0,00025^{\circ} \mathrm{C} / \mathrm{s}
\end{array}
$$

Besar nilai laju panas, $v$, dapat dituliskan pada persamaan (14)

$$
\begin{aligned}
\mathrm{v} \pm \Delta \mathrm{v}=\mathrm{M}_{\text {gradien }} & \pm \Delta \mathrm{M}_{\text {gradien }} \\
& =(0,0028 \\
& \pm 0,00025)^{\circ} \mathrm{C} / \mathrm{s}
\end{aligned}
$$

Nilai kalor jenis $C v$ dapat dituliskan sebagai persamaan (8) berikut:

$$
\begin{aligned}
C v=\frac{I^{2} R}{m \cdot M_{\text {grad }}}= & \frac{(2,4)^{2} \cdot 0,54}{209 \cdot 0,0028} \\
& =\frac{3,1104}{0,5852} \\
& =5,31 \mathrm{~J} / \text { gram }^{\circ} \mathrm{C}
\end{aligned}
$$

\begin{tabular}{|c|c|}
\hline Cairan & $\mathrm{v}$ \\
\hline Air & $(C v \pm \Delta C v)=(4$ \\
\hline $\begin{array}{l}\text { Larutan } \\
\text { Air-Garam }\end{array}$ & $(C v \pm \Delta C v)=(5,31 \pm 1,14) \mathrm{J} / \mathrm{gram}^{\circ} \mathrm{C}$ \\
\hline $\begin{array}{l}\text { dihubung } \\
\text { atau alira } \\
\text { lebih ting } \\
\text { rendah. } \mathrm{P}\end{array}$ & $\begin{array}{l}\text { rik menimbulkan panas ketil } \\
\text { ang mempunyai suhu berbec } \\
\text { atu sama lain. Ketika dua benc } \\
\text { naka akan terjadi transfer ener } \\
\text { ergi dari benda yang suhuny } \\
\text { e benda yang suhunya leb } \\
\text { eenelitian ini didapatkan hasil }\end{array}$ \\
\hline
\end{tabular}

Nilai ralat atau angka ketidakpastian besar kalor jenis dapat dituliskan sebagai persamaan (16) berikut:

$$
\begin{aligned}
& |\Delta C v|=\left|\frac{\partial C v}{\partial M g r a d} \cdot \Delta M g r a d\right| \\
& =\mid \frac{\frac{I^{2} R}{\text { M.Mgrad }}}{\text { Mgrad }} \cdot \Delta \text { Mgrad } \mid \\
& =\mid \frac{I^{2} R}{m \cdot M_{\text {grad }}^{2}} \cdot \Delta \text { Mgrad } \mid \\
& =\left|\frac{(2,4)^{2} \cdot(0,54)}{209 \cdot(0,0028)^{2}} \cdot 0,00025\right| \\
& =1,14 \mathrm{~J} / \mathrm{gram}^{\circ} \mathrm{C}
\end{aligned}
$$

Berdasarkan penelitian ini, telah berhasil diketahui $\mathrm{Cv}$ larutan seperti tercantum pada Tabel 3.

Tabel 3. Nilai Cv Air dan Larutan Garam ada perbedaan besar $\mathrm{Cv}$. Hal ini dikarenakan perubahan suhu air garam lebih kecil daripada air murni. Lalu sesuai dengan rumus yang berlaku diketahui bahwa perubahan suhu $(\Delta T)$ berbanding terbalik dengan kapasitas kalor $(\mathrm{Cv})$.

\section{PENUTUP}

Berdasarkan hasil perhitungan dan pembahasan penelitian, maka telah berhasil ditentukan kalor jenis air dan larutan garam dengan menggunakan mikrokontroler Arduino Uno, serta telah berhasil dibandingkan kalor jenis air dan larutan garam. Pada penelitian ini didapatkan hasil $C v$ air murni sebesar 4,13 $\mathrm{J} /$ gram ${ }^{\circ} \mathrm{C}$, sedangkan $\mathrm{Cv}$ air garam sebesar $5,31 \mathrm{~J} / \mathrm{gram}^{\circ} \mathrm{C}$.

\section{UCAPAN TERIMAKASIH}

Ucapan terimakasih ditujukan kepada Lab. Fisika-Mekatronika Politeknik STTT Bandung, serta rekan-rekan dosen Politeknik STTT Bandung yang telah memberikan dukungan pada penelitian ini.

\section{REFERENSI}

Ackermann, T. (1957). Hydration of $\mathrm{H}+$ and $\mathrm{OH}$ - ions in water from heat capacity measurements. Discussions of the Faraday Society, 24, 180.

Badamasi, Y. A. (2014). The working principle of an Arduino. 11th International Conference on Electronics, Computer and Computation (ICECCO).

Dean, R. N., \& Rane, A. K. (2013). A Digital Frequency-Locked Loop System for Capacitance Measurement. IEEE Transactions on Instrumentation and Measurement, 62(4), 777-784

González, T.J., Torres, S.R., Blaya, R.P., Toledo, M.A., Jiménez, B.M., \& Soto, V.F. (2019). Design and Calibration of a Low-Cost SDI12 Soil Moisture Sensor. Sensors.

Grolier, J. P. E., Benson, G. C., \& Picker, P. (1975). Simultaneous measurements of heat capacities and densities of organic liquid mixtures. Systems containing ketones. Journal of Chemical \& Engineering Data, 20(3), 243-246.

Halliday, D., Resnick, R., Walker. (1997). Fundamenthal of Physics-Extended, 5th, 
John Wiley \& Sons, New York.

Hoffmann, T., Eilebrecht, B., \& Leonhardt, S. (2011). Respiratory Monitoring System on the Basis of Capacitive Textile Force Sensors. IEEE Sensors Journal, 11(5), 1112-1119.

Kondalkar, V. V., Ryu, G., Lee, Y., \& Lee, K. (2019). Development of highly sensitive and stable humidity sensor for real-time monitoring of dissolved moisture in transformer-insulating oil. Sensors and Actuators B: Chemical.

Putra, VGV \& Purnomosari, E. (2015). Pengantar Eksperimen Fisika. Yogyakarta: CV. Mulia Jaya. ISBN: 978.602.72713.0.2.

Putra, VGV., Ngadiono, \& Purnomosari, E. (2016). Pengantar Listrik Magnet dan Terapannya. Yogyakarta: CV. Mulia Jaya. ISBN 978-60272713-2-61.

Putra, V G V, (2017), Pengantar Fisika Dasar, CV. Mulia Jaya Publisher, Yogyakarta

Putra, VGV., Ngadiono, \& Purnomosari, E. (2019). Pengantar Praktikum Mekatronika Tekstil. Yogyakarta: CV. Mulia Jaya. ISBN 9786025165832.

Picker, P., Leduc, P.-A., Philip, P. R., \& Desnoyers, J. E. (1971). Heat capacity of solutions by flow microcalorimetry. The Journal of Chemical Thermodynamics. 3(5), 631-642.

Raine, H. C., Richards, R. B., \& Ryder, H. (1945). The heat capacity, heat of solution, and crystallinity of polythene. Transactions of the Faraday Society, 41, 56

Salvo, P., Di Francesco, F., Costanzo, D., Ferrari, C., Trivella, M. G., \& De Rossi, D. (2010). A Wearable Sensor for Measuring Sweat Rate. IEEE Sensors Journal, 10(10), 15571558.

Sreejith K R ,Shyamkumar P.G, Revathy P. Appu, (2015), A low cost automated specific heat capacity meter for liquids, Ernakulam, International Conference on Trends in Automation, Communications and Computing Technology India.

Tirono, M., Sabit, A. (2011). Efek Suhu Pada Proses Pengarangan Terhadap Nilai Kalor Arang Tempurung Kelapa (Coconut Shell Charcoal). JURNAL NEUTRINO. Vol.3 